\title{
ZAKHARI STOYANOV: \\ A CHRONICLER OF THE REVOLUTIONARY \\ LIBERATION STRUGGLE OF THE BULGARIANS \\ AGAINST THE TURKS ${ }^{1}$
}

\section{Abstract:}

The article refers to the Bulgarian revolutionary, writer and publicist Zakhari Stoyanov (1850-89), who is noted the history of national literature as the creator of the monumental multi-volume work Notes on the Bulgarian Uprisings. A participant and witness to many revolutionary events, he tried to document the preparation, course and defeat of the Starozagora's (1875) and April (1876) revolts of the Bulgarians against the Turks. The writer drove around the country, interviewing the direct participants of these events, recording their oral stories and collecting relevant documentary evidence. As a result, the Bulgarians had a work that acquired the status of a kind of national Bible in the country.

\section{Keywords:}

Bulgarian national revival, journalism, memoirs, annals of the national liberation struggle of the Bulgarians against the Turks, Russophilia and Russophobia.

АННОТАЦИя: М.Г. СМОЛЬЯНИНОВА. «ЛЕТОПИСЕЦ РЕВОЛЮЦИОННО-ОСВОБОДИТЕЛЬНОЙ БОРЬБЫ БОЛГАР ПРОТИВ ТУРОК ЗАХАРИ СТОЯНОВ».

Статья посвящена болгарскому революционному писателю и публицисту Захари Стоянову (1850-89), который вошел в историю национальной литературы как создатель монументального многотомного труда «Записки по болгарским восстаниям». Участник и очевидец многих революционных событий, он попытался документально воссоздать подготовку, ход и поражение Старозагорского (1875) и Апрельского (1876) восстаний болгар против турок. Писатель ездил по стране, опрашивая непосредственных участников этих событий, записывая их устные рассказы и собирая соответствующие документальные свидетельства. В итоге у болгар появилось произведение, которое приобрело статус своеобразной национальной Библии.

\section{Ключевые слова:}

Болгарское национальное возрождение, журналистика, мемуары, летопись национально-освободительной борьбы болгар против турок, русофильство и русофобство.

7 akhari Stoyanov (1850-89) was a Bulgarian prose writer, journalist, memoirist, public figure, and revolutionary.

Stoyanov was born in the village of Medven into a peasant family, graduated from a church school, worked as a shepherd, artisan, tailor and became an active

\footnotetext{
1 The work was carried out with the financial support of the RFBR (grant № 18-512-76004).
} 
participant in the Bulgarian people's struggle for national liberation against the Ottoman enslavers. He was one of the organizers of the Starozagora's (1875) and April (1876) uprisings. After Bulgaria was liberated by the Russian troops in 1878, he wrote: "Only Russia, by word and deed, proved that it loves our people, that it desires our moral and material development." And again: "The Bulgarian people believe no one else but Russia." Later, in 1885, he led the struggle to unite the Principality of Bulgaria with Eastern Rumelia, achieving this goal with other like-minded people on 6 September 1885 (this date became one of the principal national holidays of the country). He joined the Provisional Government and later became a deputy and chairman of the National Assembly (Bulgarian Parliament). During this time, he experienced an ideological shift: by 1885 his attitude towards Rus-

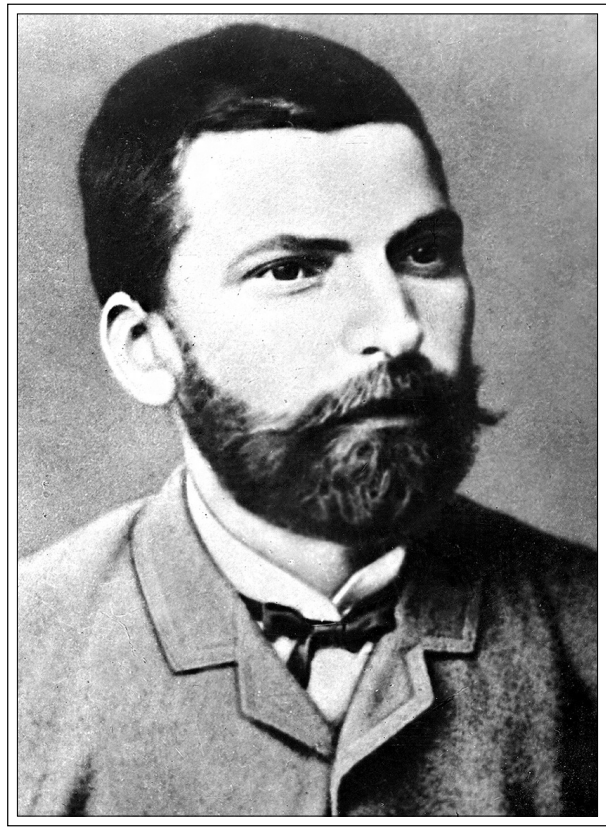

Bulgarian revolutionary, writer and politician Zakbari Stoyanov

(1850-89) sia had changed because of the Russian tsarist government's condemnation of the Union, of which it disapproved and which took place without Russia's knowledge, complicating its relations with Western European powers. From a passionate Russophile, Stoyanov turned into an ardent Russophobe. He supported the russophobic prime minister Stefan Stambolov, and created the newspaper Svoboda ("Freedom," which was the Stambolov government's official press arm), publishing articles criticizing the highest ranking Russian authorities. Zakhari Stoyanov did not live long, not even reaching the age of 40. In August 1889 he went to an international exhibition in Paris, where he fell ill and died on 2 September of the same year.

Stoyanov's literary activity began in 1880 . Together with like-minded people, the following year he founded "The Worker," newspaper in Ruse, in which he began to publish his satirical articles, literary critiques and essays related to the political struggle. Many of his publications criticized the rural rich, "Chorbadzhii," who always supported the rule of the Turkish sultan, favoring the enemy. Stoyanov then wrote the following: "Bulgaria is not yet completely free, because it was freed only from the Turks, but not from their mercenaries, the Chorbadzhii." In his articles he often recalled the names of the freedom fighters of the country Vasil Levski, Christo Botev, Lyuben Karavelov, emphasizing that he was defending the implementation of their ideals. Like Bulgarian classical writer Ivan Vazov, who 
wrote the poem The Epic of the Forgotten, Stoyanov persistently sought to perpetuate the names of these outstanding figures of the Bulgarian national revival era and to prevent them from being erased from the people's memory. He wrote books about Vasil Levski (1883), Lyuben Karavelov (1885), Christo Botev (1888), as well as a book about the Bulgarian revolutionary detachments and their leaders: "The Chetas in Bulgaria. Philip Totyu, Hadzhi Dimitar, Stefan Karadzha" (1885). In terms of genre, these books resemble fictionalized biographies.

Stoyanov's most striking work is the landmark Zapiski po balgarskite vastaniya. Razkaz na ochevidtsi. 1870-76 ("Notes on the Bulgarian Uprisings. Eyewitness Reports. 1870-76." Vol. I-III. Plovdiv. 1884-92). In these memoirs he captured the preparation of the Starozagora's and April revolts by the Bulgarians against the Turks, the course of their development and defeat. As a participant in the historical events described and not relying solely on his own memory, he traveled around the country in search of other rebels so that his work would be founded on a wider factual base, including their stories and memories. Therefore, Stoyanov's "Notes" contains a lot of documentary materials (letters, protocols, charters), but the author appears in the book not as a cold-blooded historian, but as a folk chronicler and passionate journalist. He narrates the greatness and tragedy of the national liberation struggle, creates a gallery of portraits of figures from the Bulgarian national revival: George Benkovsky, Panayot Volov, Nikola Obretenov and others. Historical authenticity is combined in the work with an artistic recreation of unforgettable events. A man of the people, a native of the "guild" of shepherds, Stoyanov set himself the task of writing a book for the poor: "I appeal to you, brothers, simple poor people, for you I sought to write a real book to show you that the most ardent fighters and defenders of our country were not proud, rich and puffed-up men of letters, but your simple and unlearned brothers." The language of "Notes" is simple, colourful, and at the same time extremely energetic and rich in folk sayings. In them the author used the traditions of national revival literature laid down by Paisius of Hilendar in his Slavo-Bulgarian History. This is

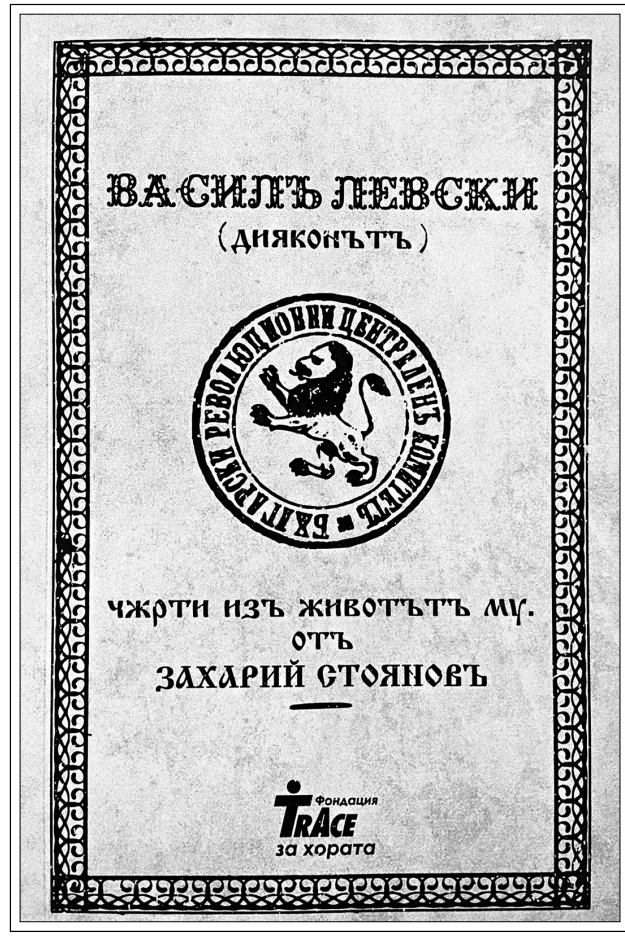

"Vasil Levski ('Deacon'). Features of his life," the cover of the Stoyanov's book on the revolutionary 
a kind of folk chronicle about the fateful historical events of the country, valued as a national Bible.

Zakhari Stoyanov is one of the heroes of the story. Notes on the Bulgarian Uprisings talks of how he turned from a poor shepherd into a writer, historian and chairman of the National Assembly (Parliament). Stoyanov tells about his life before liberation, about being a shepherd in Dobrudzha, about the life of a shepherd and the servile situation of Bulgarians in the Ottoman Empire. His father did not support his son's dream of continuing his education and for his disobedience drove him out of the house. Left without a penny in his pocket, Zakhari walked barefoot along the railroad tracks, first to Varna and then to Ruse.

He spent the night in an empty boat on the banks of the Danube, begging during the day for bread from shepherds. The young man finally found a place as an apprentice in a sewing workshop, reading books at night to expand his education. For this, he was dismissed by the master, who decided that the student was burning candles in vain and made him pay for them. Stoyanov was sheltered by the employees of the Ruse reading room "Zora," which, like other reading rooms in Bulgaria, served as a hotbed of cultural and revolutionary life for the Bulgarians. They were not merely repositories of books and newspapers - they held lectures, staged theatrical performances, recited poems, and discussed the latest political events. Zakhari Stoyanov was happy: he found himself in the world of books and other printed materials. Among them, he found a leaflet: "To arms, brothers! Death to the tyrant!" In the reading room, the young man made friends with Nikola Obretenov and other revolutionaries and became a member of the revolutionary committee.

One of the main themes of "Notes" as it was already mentioned, is the history of the two uprisings: the Starozagorsk's in September 1875 and in April in the following year. It is noteworthy that in Stara Zagora, the future writer met Stefan Stambolov. The experience of the first uprising was unsuccessful. The revolutionaries, Stefan Stambolov, Georgy Apostolov, Georgy Ikonomov, Zakhari Stoyanov and others, were forced to disperse and seek refuge in the mountains. After the failed uprising, Stoyanov worked at a railway station, living in empty railroad cars to avoid being arrested by the police.

The members of the Bucharest-based Central Bulgarian Revolutionary Committee (CBRC) decided to stage a new rebellion. On 6 February 1876, the prominent revolutionary Panayot Volov came to Stoyanov to inform him of the committee's decision to appoint him as an apostle (inspirer and leader of the 4th Plovdiv revolutionary district). Stoyanov developed his activities in the Rhodope Mountains and in Panagyurishte. In the latter he met the revolutionary Georgy Benkovsky, whom he revered. Stoyanov was enthusiastic about the fighters for the national liberation of Bulgaria and the participants in the uprisings. For him, the deputies of the Council in Oborishte were "the most honest, ideal people," patriots, brave men, ready to sacrifice themselves for the liberation of the homeland from the Turkish yoke. In his book he showed that the uprisings were truly 
popular movements that arose without external influence. In telling about the preparation for the April uprising, the author reveals the attitude of all of the social strata of Bulgarian society: peasants, artisans, clergy, Chorbadzhii, and intellectuals. The stories are often tragic and sometimes humorous.

The announcement of the beginning of the April uprising, the rebels' first victories, mass heroism, the triumph in Panagyurishte, the capture of the Bey's residence ("Konak"), the consecration of the revolutionary banner: these unforgettable scenes were described vividly, artistically and with talent by Stoyanov, an onlooker and eyewitness of these historical events. He testified that when the uprising was declared, the Turks fled from the Bulgarians so quickly that their clothes assumed a horizontal position and fluttered like wings. Then the author wrote about the catastrophe, the horror of defeat and the flight of the rebels into the mountains, where they were doomed to starvation. The Turks pursued the rebels, and many of them, including Stoyanov himself, were caught, arrested and thrown into prison. In September of the same year, Stoyanov was released from prison, because he had managed to confuse the Turkish investigators so much that they did not even understand who he really was and did not assume that they were dealing with one of the main organizers of the uprising.

During the liberation of the Russo-Turkish war of 1877-78, Stoyanov left for the city of Tarnovo, which had just been liberated by the Russians. His main literary activity flourished after the Bulgarians' liberation from Ottoman oppression.

"Notes on the Bulgarian Uprisings" had a three-fold purpose. First of all, it was an autobiography, and second, an invaluable historical document. Third, it was a literary work of art of the memoir genre. The author very realistically depicted the social, ideological and political atmosphere of the Bulgarian revival. His memoirs became an indispensable historical document of his era, raised to the level of a talented artistic generalization. Stoyanov realistically portrayed the atrocities of the Turks, the cruelty of their oppression and the heroic resistance of his compatriots against the violence directed them. "Notes on the Bulgarian Uprisings" is one of the best books in Bulgarian literature. It will always be read. It does not matter that it is a memoir, not a novel. The book affects the reader as a true work of art. Stoyanov was a talented writer of fiction who created amazing Bulgarian landscapes, expressive portraits of his comrades in the struggle for the liberation of Bulgaria and vividly outlined their unique characters. The reader is captivated by the author's narrative style, with its abundant use of colloquial speech and classical literary style. By virtue of the attributes of this voluminous work, the reader reads it to the end with unflagging interest. After all, the era of the Bulgarian national revival is revealed in it in its true greatness. 


\section{BIBLIOGRAPHY}

Konstantinov G. Zakhari Stoianov kato publitsist i pisatel. Sofia, 1952.

Mutafov E. Zakhari Stoianov i balgarskata kultura. Sofia, 2001.

Stoianov Zakhari. Sachinenia. T. 1-3. Sofia, 1983.

Stoianov Zakharii. Zapiski o bolgarskikh vosstaniiakh. Moscow, 1953.

Tsaneva M. Zakhari Stoianov // "Balgarski pisatel”, Sofia, 1973.

Zakhari Stoianov i nasheto vreme: Dokladi i nauchni saobshtenija po povod 150-god. na Letopisetsa. Sofia, 2000.

\section{ILLUSTRATIONS}

1. Bulgarian revolutionary, writer and politician Zakhari Stoyanov (1850-89).

2. Monument to the Bulgarian writer Zakhari Stoyanov in Sofia.

3. The house of Zakhari Stoyanov in Ruse.

4. Monument to Zakhari Stoyanov in Ruse.

5. Portrait of Zakhari Stoyanov. Painter Maria Stolarova, 1976.

6. "Vasil Levski ('Deacon'). Features of his life," the cover of the Stoyanov's book on the revolutionary.

7. Meeting of the Bulgarian Secret Revolutionary Committee in 1885. In the picture: Kosta Panitsa, Ivan Stoyanovich, Zakhari Stoyanov. Ivan Andronov and Dimitar Rizov.

8. Monument to Zakhari Stoyanov in Plovdiv.

9. A letter from Traycho Kitanchev to Zakhari Stoyanov with information about Vasil Levski to help the author to write a book on this revolutionary.

10. The house-museum of Zakhari Stoyanov in Medven. 